\title{
Role of inflammation in nocturnal asthma
}

Tom W Mackay, William A H Wallace, Sarah E M Howie, Peter H Brown, Andrew P Greening, Martin K Church, Neil J Douglas

\begin{abstract}
Background - Nocturnal airway narrowing is a common problem for patients with asthma but the role of inflammation in its pathogenesis is unclear. Overnight changes in airway inflammatory cell populations were studied in patients with nocturnal asthma and in control normal subjects.
\end{abstract}

Methods - Bronchoscopies were performed at 0400 hours and 1600 hours in eight healthy subjects and in 10 patients with nocturnal asthma ( $>15 \%$ overnight fall in peak flow plus at least one awakening/week with asthma). The two bronchoscopies were separated by at least five days, and both the order of bronchoscopies and site of bronchoalveolar lavage (middle lobe or lingula with contralateral lower lobe bronchial biopsy) were randomised.

Results - In the normal subjects there was no difference in cell numbers and differential cell counts in bronchoalveolar lavage fluid between 0400 and 1600 hours, but in the nocturnal asthmatic subjects both eosinophil counts (median $0.11 \times 10^{5}$ cells $/ \mathrm{ml}$ at 0400 hours, $0.05 \times 10^{5}$ cells/ml at 1600 hours) and lymphocyte numbers $\left(0.06 \times 10^{5}\right.$ cells $/ \mathrm{ml}$ at 0400 hours, $0.03 \times 10^{5}$ cells $/ \mathrm{ml}$ at 1600 hours) increased at 0400 hours, along with an increase in eosinophil cationic protein levels in bronchoalveolar lavage fluid $(3.0 \mu \mathrm{g} / \mathrm{ml}$ at 0400 hours, $2.0 \mu \mathrm{g} / 1$ at 1600 hours). There were no changes in cell populations in the bronchial biopsies or in alveolar macrophage production of hydrogen peroxide, GM-CSF, or TNF $\alpha$ in either normal or asthmatic subjects at 0400 and 1600 hours. There was no correlation between changes in overnight airway function and changes in cell populations in the bronchoalveolar lavage fluid. Conclusions - This study confirms that there are increases in inflammatory cell populations in the airway fluid at night in asthmatic but not in normal subjects. The results have also shown a nocturnal increase in eosinophil cationic protein levels in bronchoalveolar lavage fluid, but these findings do not prove that these inflammatory changes cause nocturnal airway narrowing.

(Thorax 1994;49:257-262)

Nocturnal cough, wheeze, or chest tightness waken more than $90 \%$ of asthmatic subjects at least once a month. ${ }^{12}$ These symptoms result from overnight airway narrowing, the causes of which include increased parasympathetic tone $^{34}$ and decreased non-adrenergic, noncholinergic bronchodilator tone. ${ }^{5}$ Increased bronchoconstrictor mediator release has also been suggested as a factor in the pathogenesis of nocturnal asthma, ${ }^{6-8}$ but a recent study has cast some doubt on the importance of this mechanism. ${ }^{9}$

Increased numbers of neutrophils, eosinophils, and lymphocytes have been found in the bronchoalveolar lavage (BAL) fluid of patients with nocturnal asthma at 0400 hours, but not in a group of asthmatic subjects without nocturnal symptoms. ${ }^{10}$ However, the concentration of mediators in BAL fluid was not assessed, nor were the possible changes in the bronchial mucosal cell populations. To clarify the role of inflammation, and particularly the role of eosinophils and lymphocytes, in the pathogenesis of nocturnal asthma, we have therefore performed bronchial biopsies and BAL in patients with nocturnal asthma. We also studied normal subjects to clarify whether any changes found in the asthmatic patients were a result of circadian variations also observed in normal subjects.

\section{Methods}

\section{SUBJECTS}

Eight normal non-smoking subjects (six men, two atopic) of mean age 34 (range 28-42) years and ten non-smoking patients with nocturnal asthma (four men, six atopic) of mean age 36 (range 21-49) years were studied (table 1). Nocturnal asthma was defined as a minimum $15 \%$ overnight fall in peak expiratory flow (PEF) and at least one night time wakening per week due to cough, wheeze, or breathlessness over a two week run in period. Each subject gave written informed consent to the study which had the approval of the local ethics committee.

\section{BRONCHOSCOPY}

Bronchoscopy was performed at 0400 and 1600 hours, the order being randomised. The bronchoscopies were separated by at least five days, and nine of the 18 subjects had their first bronchoscopy at 0400 hours. No drug dosages were withheld before bronchoscopies. Both normal and asthmatic subjects were premedicated with nebulised salbutamol $(5 \mathrm{mg})$ and ipratropium ( $0.5 \mathrm{mg}$ ) from an Acorn nebuliser 20 minutes before bronchoscopy. Thereafter, all subjects had an $\mathrm{FEV}_{1}$ of more than $50 \%$ predicted before bronchoscopy. A peripheral venous catheter was inserted and blood samples were taken for differential white cell counts. All received $0.6 \mathrm{mg}$ atropine, $5-10 \mathrm{mg}$ midazolam, and $2 \cdot 5-7.5 \mathrm{mg}$ Cyclimorph intra- 
Table 1 Characteristics of patients with nocturnal asthma

\begin{tabular}{llllrl}
\hline Age/Sex & $\begin{array}{l}F E V_{l} \\
\text { at } 0400 \text { hours } \\
(\%)\end{array}$ & $\begin{array}{l}\text { FEV } \\
\text { at } 1600 \text { hours } \\
(\%)\end{array}$ & Drugs* & $P D_{20}{ }^{\dagger}$ & $\begin{array}{l}\text { Overnight } \\
\text { fall in } \\
\text { PEF }(\%) \ddagger\end{array}$ \\
\hline $38 / \mathrm{F}$ & 80 & 97 & B,A,T,S & 70 & 17 \\
$42 / \mathrm{F}$ & 84 & 98 & B,S & 11 & 21 \\
$34 / \mathrm{M}$ & 52 & 67 & B,T,S & 70 & 21 \\
$39 / \mathrm{F}$ & 88 & 94 & B,A,S & 79 & 18 \\
$49 / \mathrm{M}$ & 71 & 81 & B,T,S,C & 770 & 20 \\
$45 / \mathrm{M}$ & 90 & 98 & B & 1175 & 16 \\
$45 / \mathrm{M}$ & 62 & 77 & B,T,S & 60 & 20 \\
$21 / \mathrm{F}$ & 51 & 63 & B,S & 17 & 34 \\
$32 / \mathrm{F}$ & 60 & 75 & B,S & 21 & 40 \\
$24 / \mathrm{F}$ & 28 & 83 & B,S & 11 & 66 \\
Mean (SE) & $63(6)$ & $83(4)$ & - & - & $29(6)$ \\
\hline
\end{tabular}

${ }^{*} \mathrm{~B}=$ inhaled $\beta_{2}$ agonist; $\mathrm{A}=$ inhaled anticholinergic; $\mathrm{T}=$ oral theophylline; $\mathrm{S}=$ inhaled corticosteroid; $\mathrm{C}=$ inhaled disodium cromoglycate.

$\mathrm{PD}_{20} \mathrm{FEV}$, histamine: geometric mean $98 \mathrm{ng}$.

$\ddagger$ Mean $\%$ overnight fall in peak expiratory flow during run-in period.

venously immediately before bronchoscopy. Lignocaine $2 \%$ spray was applied topically to the nose, pharynx, larynx, and bronchi as required. Oxygen was delivered at a rate of $31 /$ min via nasal cannulae continuously during bronchoscopy. Electrocardiography and oximetry were recorded throughout.

The sites of bronchial biopsy and bronchoalveolar lavage were also randomised. On one occasion lavage was performed in the middle lobe and bronchial biopsies were taken from subsegmental carinae in the left lower lobe, and on the other occasion lavage was performed in the lingula and biopsies were performed from subsegmental carinae of the right lower lobe. Lavage was performed with $8 \times 30 \mathrm{ml}$ aliquots of sterile normal saline at $37^{\circ} \mathrm{C}$ with the bronchoscope wedged in a subsegmental division.

\section{ASSAYS}

Bronchoalveolar lavage

The lavage sample was centrifuged at $4^{\circ} \mathrm{C}$. The BAL fluid was removed and stored at $-70^{\circ} \mathrm{C}$. The cells were washed twice with phosphate buffered saline and counted with a haemocytometer. Cytospins were made using $0.5 \times 10^{5}$ cells per slide at $300 \mathrm{rpm}$ for three minutes and fixed with methanol before staining with Giemsa. Differential cell counts were performed, without knowledge of the patient's diagnosis or the time of the sample, by light microscopy at $400 \times$ magnification, counting a minimum of 400 cells in five random fields.

Histamine, eosinophil cationic protein, and tryptase were assayed in the BAL fluid. Histamine was assayed using a commercial radioimmunoassay kit (Serotec, Oxford, UK). The sample was acylated and the modified histamine competed with ${ }^{125} \mathrm{I}$-acylated histamine for binding sites on antihistamine antibody coated tubes. Eosinophil cationic protein in the BAL fluid was assayed using a commercial radioimmunoassay kit (Pharmacia, Milton Keynes, UK). Sample eosinophil cationic protein competed against a fixed volume of ${ }^{125} \mathrm{I}$-eosinophil cationic protein for binding sites on specific antibodies. The addition of a second antibody immunosorbent separated the bound and free eosinophil cationic protein following centrifugation and decanting. Tryptase was assayed with a modified commercial coated tube radioimmunoassay (Pharmacia, Milton Keynes, UK). The sample of BAL fluid was incubated on an agitator overnight at room temperature with a fixed volume of "in-house" AA5 coupled sepharose antibody. After washing, a fixed volume of ${ }^{125} \mathrm{I}$-antitryptase was added and inoculated overnight at room temperature. After incubation unbound ${ }^{125} \mathrm{I}$-antitryptase was removed by washing and centrifugation. The remaining radioactivity was directly proportional to the concentration of tryptase in the sample. Standard curves were constructed with linear portions between $0.5-150 \mathrm{nM}$ for histamine, $2 \cdot 0-200 \cdot 0 \mu \mathrm{g} / 1$ for eosinophil cationic protein, and $2 \cdot 0-50 \cdot 0$ units/l for tryptase.

\section{Macrophage function}

Cells from BAL fluid were resuspended in medium RPMI 1640 (Gibco, Paisley, UK) at $1 \times 10^{6}$ macrophages $/ \mathrm{ml}$, and the macrophages enriched by plastic adherence for one hour in $35 \mathrm{~mm}$ petri dishes (Corning, Stone, UK). The cells were then washed in Hank's balanced salt solution (HBSS) with $25 \mathrm{mmol} / \mathrm{l}$ Hepes buffer (Gibco) and the non-adherent cells were counted. The macrophages were cultured in RPMI 1640, supplemented by $15 \%$ lipopolysaccharide-free fetal bovine serum, for 20 hours. The supernatants were aspirated, centrifuged to remove any detached cells, and stored at $-80^{\circ} \mathrm{C}$ until batch assay by ELISA (inhouse) for $T N F \alpha$ and GM-CSF. Data were expressed as $\mathrm{ng} / 10^{6}$ macrophages $/ 20$ hours. The adherent macrophages were washed (HBSS) and phorbol ester stimulated hydrogen peroxide release was measured ${ }^{11}$ by the change in fluorescence intensity of $p$-hydroxyphenylacetic acid, during its oxidation, catalysed by horseradish peroxidase. $^{12}$ Data were expressed as nmol hydrogen peroxide $/ 10^{6}$ macrophages/hour.

\section{Bronchial biopsies}

The bronchial biopsies (at least three from each individual) were placed in OCT compound (Miles Inc, Illinois, USA), immediately snap frozen with liquid nitrogen in the theatre, and stored at $-70^{\circ} \mathrm{C}$. Sections were cut and fixed with acetone. Sections from each block were stained with haematoxylin and eosin and viewed to confirm that adequate bronchial tissue was present. Further sections from each case were then stained by a standard indirect immunoperoxidase technique to identify the total inflammatory cell infiltrate (CD45; Dako Ltd, UK), the $T$ lymphocyte population (CD3; Dako Ltd, UK), and eosinophils (EG2; Sera-Lab, Sussex, UK). Endogenous peroxidase activity in the tissues was blocked with hydrogen peroxide. Sections were counterstained with haematoxylin and mounted.

The number of positive cells in the submucosa for each case was counted by light microscopy at $400 \times$ magnification with the aid of an eyepiece graticule (Graticules Ltd, Kent, UK) without knowledge of the time or subject group. The total submucosal area for each section, excluding glands and any smooth muscle components, was then measured using the IBAS II, a semi-automated image analysis system (Kontron Image Analysis Division, 
Table 2 Median (range) absolute cell counts $\left(\times 10^{9} / l\right)$ in peripheral blood in normal and asthmatic subjects at 0400 hours and 1600 hours

\begin{tabular}{|c|c|c|}
\hline & 0400 hours & 1600 hours \\
\hline $\begin{array}{l}\text { Normal subjects } \\
\text { Total white cells } \\
\text { Neutrophils } \\
\text { Lymphocytes } \\
\text { Monocytes } \\
\text { Eosinophils } \\
\text { Basophils }\end{array}$ & $\begin{array}{l}6.55(4.50-8.00) \\
3.69(2.94-4.62) \\
2.48(1.14-2.78) \\
0.33(0.20-0.37) \\
0.15(0.06-0.50) \\
0.07(0.03-0.09)\end{array}$ & $\begin{array}{l}6.10(3.30-8.80) \\
3.83(1.47-5.80) \\
1.80(1.52-2.43)^{*} \\
0.31(0.14-0.81) \\
0.12(0.05-0.20) \\
0.05(0.02-0.09)^{*}\end{array}$ \\
\hline $\begin{array}{l}\text { Asthmatic subjects } \\
\text { Total white cells } \\
\text { Neutrophils } \\
\text { Lymphocytes } \\
\text { Monocytes } \\
\text { Eosinophils } \\
\text { Basophils }\end{array}$ & $\begin{array}{l}7.60(5.40-11.40) \\
3.60(2.45-7 \cdot 16) \\
2.63(1.87-3.69) \\
0.45(0.19-1 \cdot 10) \\
0.26(0.16-0.72) \\
0.06(0.03-0.14)\end{array}$ & $\begin{array}{l}9.10(5.40-12.60)^{*} \\
5.79(2.88-8.51)^{* *} \\
2.04(1.17-2.75)^{*} \\
0.29(0.18-1.20) \\
0.41(0.04-0.53) \\
0.07(0.03-0.11)\end{array}$ \\
\hline
\end{tabular}

${ }^{*} \mathrm{p}<0.05,{ }^{* *} \mathrm{p}<0.01 v$ counts at 0400 hours

Munich, Germany), and the number of positive cells expressed per $\mathrm{mm}^{2}$ submucosal area.

\section{$P D_{20}$ histamine}

The provocative dose of histamine causing a $20 \%$ fall in forced expiratory volume in one second $\left(\mathrm{PD}_{20} \mathrm{FEV}_{1}\right)$ was assessed by increasing doses of histamine $(10-1600 \mu \mathrm{g})$ delivered from an automatic inhalation synchronised dosimeter jet nebuliser (Spira, Elektro 2 Respiratory Care Center, Hameenlinna, Finland).

\section{STATISTICAL ANALYSIS}

Data are expressed as medians with range or mean (SE) as appropriate. Spirometry data were analysed with the Student's $t$ test. Bronchoalveolar lavage, bronchial biopsy, and peripheral blood data were not normally distributed and were therefore analysed with the Wilcoxon signed rank test.

\section{Results}

SAFETY ASPECTS

All subjects tolerated two bronchoscopies. No bronchoscopy had to be terminated early in either group, although one asthmatic patient required salbutamol solution via the bronchoscope after BAL because of bronchoconstriction. No subject complained of prolonged cough, wheeze, or breathlessness after the procedure.

\section{Normal subjects}

Before administration of bronchodilators the mean (SE) FEV, was $107 \%(4 \%)$ predicted at

Table 3 Median (range) absolute cell counts $\left(\times 10^{5} / l\right)$ in bronchoalveolar lavage fluid in normal and asthmatic subjects at 0400 and 1600 hours

\begin{tabular}{|c|c|c|}
\hline & 0400 hours & 1600 hours \\
\hline $\begin{array}{l}\text { Normal subjects } \\
\text { Total cell } \\
\text { Macrophages } \\
\text { Lymphocytes } \\
\text { Neutrophils } \\
\text { Eosinophils }\end{array}$ & $\begin{array}{l}0.62(0.33-1.44) \\
0.54(0.28-1.32) \\
0.045(0.019-0.076) \\
0.005(0-0.019) \\
0.012(0.002-0.036)\end{array}$ & $\begin{array}{l}0.36(0.25-1.04) \\
0.32(0.24-0.96) \\
0.032(0.008-0.052) \\
0.004(0-0.024) \\
0.004(0-0.031)\end{array}$ \\
\hline $\begin{array}{l}\text { Asthmatic subjec } \\
\text { Total cell } \\
\text { Macrophages } \\
\text { Lymphocytes } \\
\text { Neutrophils } \\
\text { Eosinophils }\end{array}$ & $\begin{array}{l}1.21(0.56-4.20) \\
0.98(0.44-3.46) \\
0.06(0.02-0.23) \\
0(0-0.05) \\
0.11(0.01-0.31)\end{array}$ & $\begin{array}{l}1.15(0.06-2.30) \\
0.89(0.58-1.99) \\
0.03(0.01-0.14)^{*} \\
0(0-0.02) \\
0.05(0.008-0.07)^{*}\end{array}$ \\
\hline
\end{tabular}

${ }^{*} \mathrm{p}<0.05 v$ counts at 0400 hours.
0400 hours and $106 \%(4 \%)$ predicted at 1600 hours. The percentage fall in $\mathrm{FEV}_{1}$ following bronchoscopy was similar at both times $(8 \%$ $(4 \%)$ and $3 \%(2 \%))$.

\section{Asthmatic subjects}

Before administration of bronchodilators the mean (SE) $\mathrm{FEV}_{1}$ was $63 \%$ (6\%) predicted at 0400 hours and $83 \%(4 \%)$ predicted at 1600 hours, with a mean overnight fall in PEF of $29 \%(6 \%)$. The percentage fall in FEV following bronchoscopy was similar at both times $(27 \%(5 \%)$ and $29 \%(4 \%))$.

\section{PERIPHERAL BLOOD ANALYSIS}

Normal subjects

There was no change in numbers of total white cells, neutrophils, or eosinophils at 0400 hours compared with 1600 hours (table 2). Lymphocyte and basophil numbers were increased at 0400 hours compared with 1600 hours.

\section{Asthmatic subjects}

An increase in total cell count was seen at 1600 hours compared with 0400 hours (table 2) mainly as a result of an increase in neutrophil numbers at 1600 hours. Lymphocytes were significantly increased at 0400 hours. There were no significant differences in eosinophil or basophil numbers.

\section{BRONCHOALVEOLAR LAVAGE FLUID}

Normal subjects

There was no difference in the absolute or percentage return of lavage fluid between 0400 hours and 1600 hours $(69 \%(2 \%)$ and $69 \%$ $(4 \%))$. There was no difference in the total cell count in BAL fluid between the time points (table 3), nor was there any difference in any individual cell type (table 3 ).

\section{Asthmatic subjects}

There was no significant difference in the percentage return of lavage fluid at 0400 hours and 1600 hours $(55 \%(5 \%)$ and $63 \%(3 \%))$. There was no difference in total white cell count in the BAL fluid between both time points (table 3), but there was a significant increase in both lymphocyte and eosinophil numbers at 0400 hours (fig 1).

\section{Bronchoalveolar lavage fluid mediators}

There was no significant difference in eosinophil cationic protein, histamine or tryptase levels in the fluid between 0400 and 1600 hours in the normal subjects (table 4, fig 2). In the patients with nocturnal asthma the levels of eosinophil cationic protein in BAL fluid were significantly higher at 0400 hours than at 1600 hours (table 4), but there was no significant difference between levels of histamine and tryptase at the two time points. 


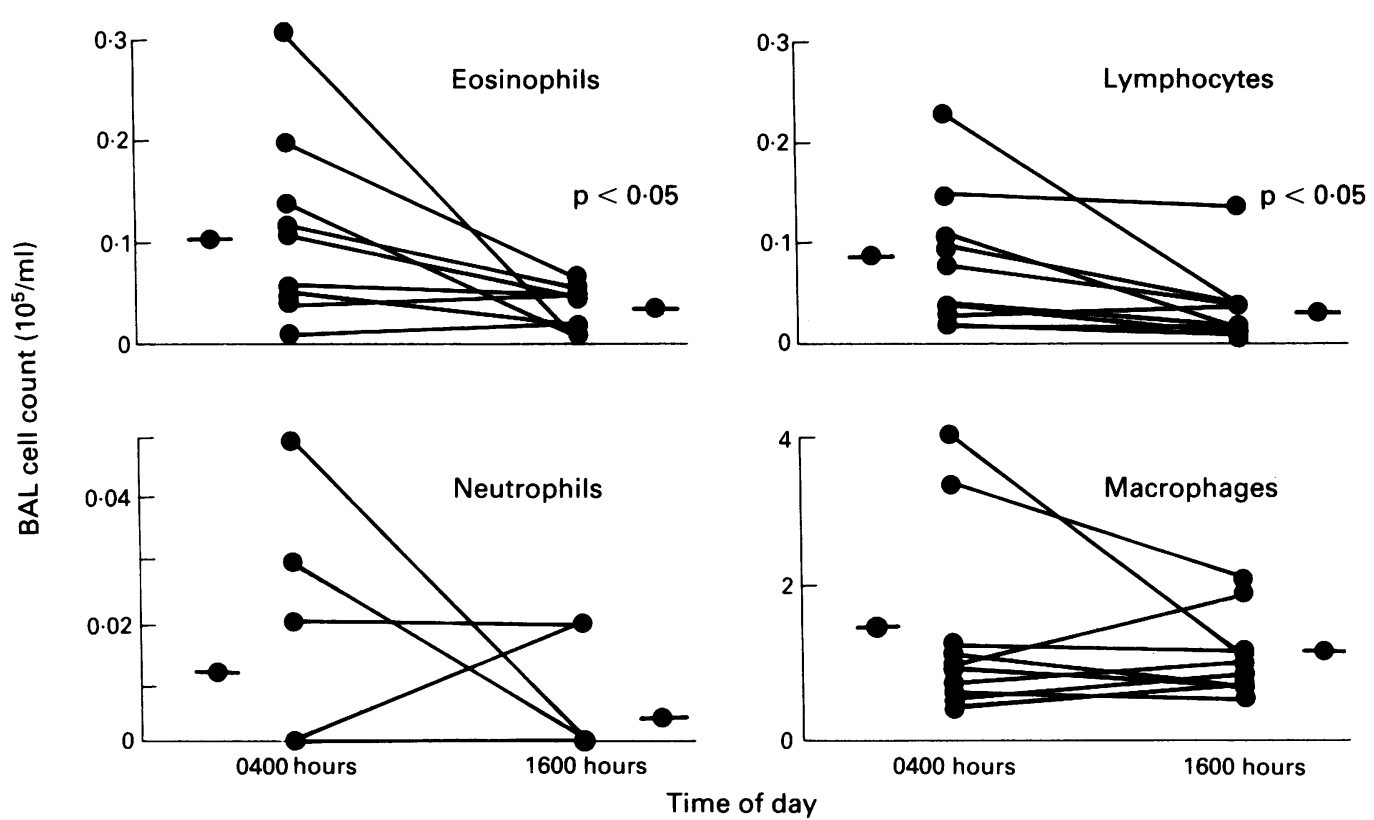

Figure 1 Cell counts in bronchoalveolar lavage fluid at 0400 hours and 1600 hours in the patients with nocturnal asthma. There were significant falls in eosinophil and lymphocyte numbers at 1600 hours but no significant changes in neutrophil or macrophage numbers.

\section{Macrophage function}

There was no significant difference in macrophage production of hydrogen peroxide between the two times in either normal subjects $\left(11.2(2.0)\right.$ and $11.8(2.0) \mathrm{nmol} / 10^{6}$ macrophages/hour) or asthmatic subjects $(5.8(1.5)$ and $7 \cdot 3(2 \cdot 0) \mathrm{nmol} / 10^{6}$ macrophages/hour). Similarly, there was no significant difference in $\mathrm{TNF} \alpha$ production between the two times in either the normal subjects (173 (32) and 106 (16) $\mathrm{ng} / 10^{6}$ macrophages/20 hours) or in the patients with nocturnal asthma (140 (59) and 245 (50) $\mathrm{ng} / 10^{6}$ macrophages/20 hours), nor was there any significant differences in GMCSF production between the two times (normal subjects $102(42)$ and $72(42) \mathrm{ng} / 10^{6} \mathrm{mac}-$ rophages/20 hours; asthmatics $26(9)$ and 223 (93) $\mathrm{ng} / 10^{6}$ macrophages/20 hours).

\section{Bronchial biopsies}

There was no evidence of an increase in inflammatory cell numbers in the bronchial submucosa at 0400 hours compared with 1600 hours in either group. This was the case whether the data were analysed in terms of cells/unit area of submucosa (table 5) or cells $/ \mathrm{mm}$ basement membrane. Four of the normal subjects had higher eosinophil counts in their bronchial biopsies at $\mathbf{1 6 0 0}$ hours for no obvious reason.

Table 4 Median (range) concentrations of inflammatory mediators in normal and asthmatic subjects at 0400 hours and 1600 hours

\begin{tabular}{|c|c|c|}
\hline & 0400 hours & 1600 hours \\
\hline $\begin{array}{l}\text { Normal subjects } \\
\text { Histamine (nM) } \\
\text { Tryptase (units/l) } \\
\text { ECP }(\mu \mathrm{g} / \mathrm{l})\end{array}$ & $\begin{array}{l}0 \cdot 60(0 \cdot 50-2 \cdot 20) \\
0 \cdot 10(0 \cdot 04-0 \cdot 21) \\
2 \cdot 0(2 \cdot 0-2 \cdot 0)\end{array}$ & $\begin{array}{l}0.50(0.50-2.50) \\
0.11(0.06-0.54) \\
2.0(2.0-3.4)\end{array}$ \\
\hline $\begin{array}{l}\text { Asthmatic subjects } \\
\text { Histamine (nM) } \\
\text { Tryptase (units/l) } \\
\operatorname{ECP}(\mu \mathrm{g} / \mathrm{l})\end{array}$ & $\begin{array}{l}1.50(0.50-35 \cdot 3) \\
0.37(0 \cdot 10-2 \cdot 00) \\
3.0(2 \cdot 0-9 \cdot 7)\end{array}$ & $\begin{array}{l}1.60(0.5-30 \cdot 6) \\
0 \cdot 26(0.07-1 \cdot 03) \\
2 \cdot 0(2 \cdot 0-4 \cdot 1)^{*}\end{array}$ \\
\hline
\end{tabular}

$\mathrm{ECP}=$ eosinophil cationic protein

${ }^{*} \mathrm{p}<0.01 v$ value at 0400 hours.
Comparison between asthmatic and normal subjects

When the differences in cell numbers and mediators at 0400 and 1600 hours were compared in the asthmatic and normal subjects there were significant differences for total cell numbers and neutrophils in peripheral blood $(p<0 \cdot 05)$, but no significant differences in the changes in cell populations between the asthmatic and normal subjects for either bronchoalveolar lavage or bronchial biopsies. There was a significantly greater increase $(p<0.01)$ in the level of eosinophil cationic protein in BAL fluid at 0400 hours in the asthmatic subjects.

\section{CORRELATION BETWEEN PULMONARY FUNCTION} AND INFLAMMATORY CELL NUMBERS

In the patients with nocturnal asthma there were no significant correlations between the overnight percentage fall in PEF and the absolute or percentage change in total cell count, lymphocytes, neutrophils, or eosinophils in BAL fluid. There were no significant correlations between overnight percentage fall in PEF and overnight absolute or percentage change in peripheral total blood cell count for any individual cell type. In addition, the patient with the largest fall in PEF at night $(66 \%)$ had fewer eosinophils $(1 \% v 4 \%)$ in their BAL fluid at 0400 hours than at 1600 hours and unchanged lymphocyte numbers $(1 \%)$. There was a significant correlation between the $\mathrm{PD}_{20}$ and change in baseline FEV between the time points $(r=0.90, \mathrm{p}<0.001)$.

\section{Discussion}

This study shows a significant increase in lymphocyte and eosinophil numbers in BAL fluid at 0400 hours compared with 1600 hours, and an increase in eosinophil cationic protein levels in BAL fluid in patients with nocturnal asthma but no change in any of these variables 
Table 5 Median (range) numbers of cells $/ \mathrm{mm}^{2}$ in the bronchial submucosa of normal and asthmatic subjects at 0400 hours and 1600 hours

\begin{tabular}{lcc}
\hline & 0400 hours & 1600 hours \\
\hline Normal subjects & $561(116-989)$ & \\
CD45 & $507(14-830)$ & $369(217-584)$ \\
CD3 & $177(5-535)$ & $203(141-571)$ \\
CD4 & $8 \cdot 1(0-16 \cdot 4)$ & $80(45-146)$ \\
EG2 & & $48(0-293)$ \\
Asthmatic subjects & $246(49-627)$ & \\
CD45 & $199(19-443)$ & $202(28-1057)$ \\
CD3 & $107(5-145)$ & $35(0-232)$ \\
CD4 & $13 \cdot 1(0-61 \cdot 8)$ & $10 \cdot 9(0-119)$ \\
\hline
\end{tabular}

Figure 2 Concentrations of mediators in bronchoalveolar lavage fluid in the patients with nocturnal asthma at 0400 hours and 1600 hours.

The concentration of eosinophil cationic protein $(E C P)$ was significantly lower at 1600 hours than at 0400 hours. in normal subjects. There was, however, no significant increase in total cell numbers in BAL fluid at 0400 hours, and no change in submucosal inflammatory cell numbers in the bronchial biopsies in the nocturnal asthmatic subjects at 0400 hours. In the patients with nocturnal asthma there was a significant rise in peripheral blood lymphocyte count and fall in peripheral blood neutrophil count at 0400 hours but no significant change in peripheral blood eosinophil numbers.

Our results confirm and extend the observations of Martin et $a l^{10}$ of an increase in inflammatory cells in BAL fluid at 0400 hours in patients with nocturnal asthma. In particular, we have confirmed a significant elevation of eosinophil numbers, but we have also found an increase in lymphocyte numbers which was not evident in the study by Martin et al. In contrast to our study, Martin and colleagues found a doubling of total white cells in BAL fluid at 0400 hours in patients with nocturnal asthma, and a trebling of neutrophil numbers, whereas Jarjour et $a l,{ }^{13}$ like us, failed to find
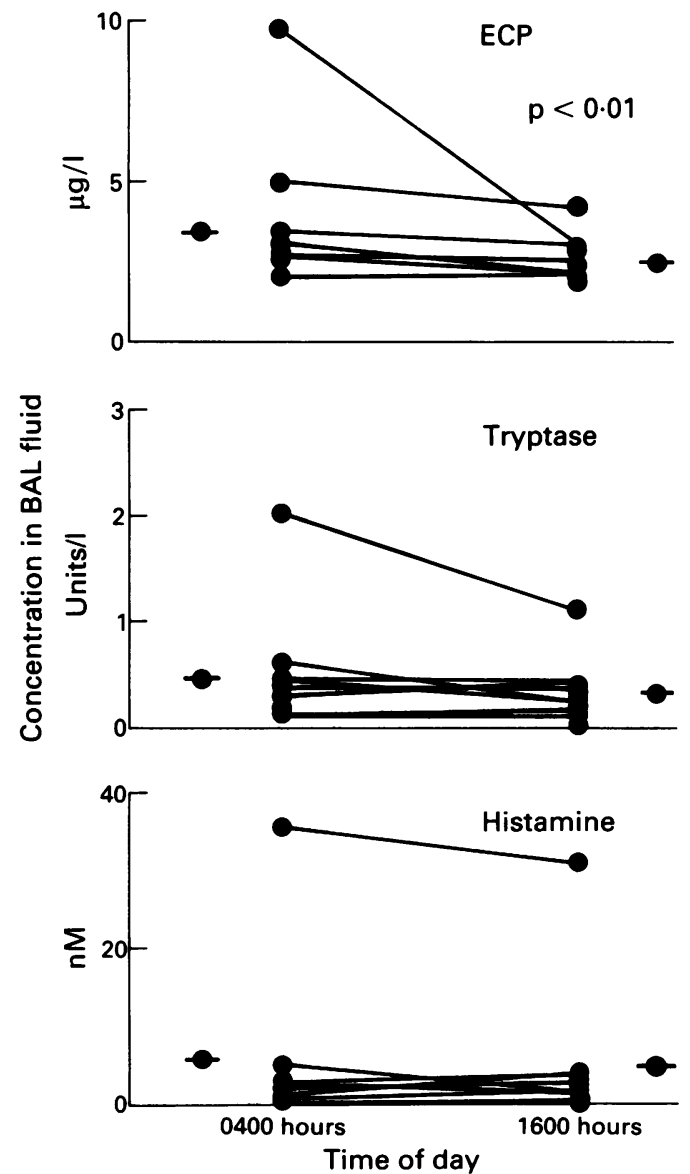

any increase in total white cell numbers in BAL fluid at 0400 hours compared with 1600 hours in patients with nocturnal asthma.

The total white cell count in BAL fluid reported in the study of Martin and colleagues $^{10}$ was 2-3 times higher than that recorded in the present study, and there may be methodological differences to account for this. For example, our nocturnal asthmatic subjects had a slightly smaller overnight fall in PEF (29\% (6\%) v 40\% (3\%)) and nine of the 10 subjects were receiving inhaled steroids, whereas none of those studied by Martin were receiving these drugs. In the United Kingdom it is recommended that all patients with recognised nocturnal asthma should be treated with inhaled steroids ${ }^{14}$ and we did not consider it ethically acceptable to stop these drugs for this study. Inhaled steroids were taken by all patients on a twice daily regime, and at an identical period before each of the two bronchoscopies. Their use may certainly have altered the results, and it is possible, for example, that the proximal deposition of inhaled steroids in the bronchial tree may have modified the inflammatory cell population in the bronchial biopsies ${ }^{15}$ and possibly in the BAL fluid too. However, the use of inhaled steroids may have allowed us to show that some of the changes previously reported as potential causes of nocturnal bronchoconstriction - for example, the increase in neutrophils in BAL fluid - are not necessary factors for the airways to narrow at night. Another difference between the study of Martin and colleagues ${ }^{10}$ and our own is the fact that in their study all lavages were performed from the same lobe and the two bronchoscopies were separated by only four days in four of the seven nocturnal asthmatic subjects. Repeat bronchoalveolar lavage in the same lobe has been shown to increase inflammatory cell numbers. ${ }^{16}$ The longest interval between repeat bronchoscopies in that study ${ }^{16}$ was three days when there was a tenfold increase in neutrophil numbers - although statistically non-significant in the five subjects studied - and, furthermore, the subjects studied were not asthmatic $^{16}$. The lack of correlation between changes in cell numbers in BAL fluid and the overnight fall in PEF raises doubts as to whether the changes in inflammatory cell population cause overnight airway narrowing. Indeed, the patient with the largest overnight fall in PEF had fewer eosinophils and unchanged lymphocyte numbers in the BAL specimens taken at 0400 hours. However, the number of subjects with nocturnal asthma studied was relatively small at 10 - albeit three more than in the study by Martin et $a l^{10}$ and five more than Jarjour et $a l^{11}$ - and this conclusion needs to be re-examined when more nocturnal asthmatic subjects have been studied.

The increase in numbers of lymphocytes, eosinophils, and eosinophil cationic protein at 0400 hours in the patients with nocturnal asthma does indicate changes in lung inflammatory cell populations and mediator release overnight, but the significance of these changes requires further investigation. The 
finding of parallel increases in eosinophils and lymphocytes in BAL fluid at night is compatible with similarities in the factors controlling migration of these two cell types from the blood to the tissues. Eosinophils and lymphocytes share the capacity to adhere to VCAM-1 expressed on activated vascular endothelium. ${ }^{1718}$ VCAM-1 expression increases after allergen challenge ${ }^{19}$ and is increased when stimulated by IL- 4 released from mast cells and Th2 lymphocytes. ${ }^{2021}$ In addition, both eosinophils and lymphocytes are attracted by two lymphokines, IL-2 and lymphocyte chemoattractant factor. ${ }^{22}$

The lack of change in cell populations in the bronchial biopsies in the patients with nocturnal asthma, despite significant changes in cell populations in BAL fluid, might reflect differences in sampling location or cell kinetics. The bronchial biopsies were taken at the subsegmental carinae whereas BAL fluid is derived from the more distal airways. It is possible, therefore, that there were changes in the submucosal airway cell populations distal to the sites of biopsy, perhaps reflecting more proximal deposition of inhaled steroids. It is equally possible that the inflammatory cells sampled in the BAL fluid had migrated through the airway submucosa earlier in the night and had left the submucosa before the bronchial biopsies were performed.

The rise in the level of eosinophil cationic protein in BAL fluid at night contrasts with our finding of an overnight fall in plasma levels of eosinophil cationic protein at night in patients with nocturnal asthma. ${ }^{10}$ The concentration in BAL fluid is much more likely to reflect changes in airway concentrations of mediators than is the concentration in peripheral venous blood, and the current results may reflect flux of eosinophils into the airway at night.

Jarjour and colleagues ${ }^{13}$ found an increase in superoxide production from alveolar macrophages in the early morning in patients with nocturnal asthma. We failed to find any evidence of increased production of hydrogen peroxide from macrophages in the early morning, nor could we detect any significant changes in cytokine production by the alveolar macrophages at this time, although there was a tendency towards increased GM-CSF production in the nocturnal asthmatic subjects at 0400 hours.

Our results suggest that there are increases in some airway inflammatory cells and mediators at night in patients with nocturnal asthma. The precise role of this in the pathogenesis of nocturnal airway narrowing, and its interaction with, and relative importance to, changes in autonomic tone which predispose to nocturnal airway narrowing remains to be clarified.
The authors thank $M$ Bain, E Ramage, and $M$ Luke for technical and nursing assistance.

1 Turner-Warwick $M$. Nocturnal asthma: a study in general practice. $\mathcal{F} R$ Coll Gen Pract 1989;39:239-43.

2 Fitzpatrick MF, Martin K, Fossa E, Shapiro C, Elton RA, Douglas NJ. Snoring, asthma and sleep disturbance in Britain: a community based survey. Eur Respir $\mathcal{f}$ 1993;6:531-5.

3 Catterall JR, Rhind GB, Whyte KF, Shapiro CM, Douglas NJ. Is nocturnal asthma caused by changes in airway cholinergic activity? Thorax 1988;43:720-4.

4 Morrison JF, Pearson SB, Dean HG. Parasympathetic nervous system in nocturnal asthma. $B M \mathcal{J}$ 1988;296:1427-9.

5 Mackay TW, Fitzpatrick MF, Douglas NJ. Non-adrenergic, non-cholinergic nervous system and overnight airway calibre in asthmatic and normal subjects. Lance 1991;338:1289-91.

6 Barnes P, Fitzgerald G, Brown MJ, Dollery C. Nocturnal asthma and changes in circulating epinephrine, histamine and cortisol. N Engl f Med 1980;303:263-7.

7 van Aalderen WMC, Postma DS, Koeter GH, Knol K. Nocturnal airflow obstruction, histamine, and the autonomic central nervous system in children with allergic asthma. Thorax 1991;46:366-71.

8 Szefler SJ, Ando R, Cicutto LC, Surs W, Hill MR, Martin RJ. Plasma histamine, epinephrine, cortisol, and leukocyte $\beta$-adrenergic receptors in nocturnal asthma. Clin cyte $\beta$-adrenergic receptors in
Pharmacol Ther 1991;49:59-68.

9 Fitzpatrick MF, Mackay TW, Walters C, Tai P, Church MK, Holgate ST, et al. Circulating histamine and eosinophil cationic protein levels in nocturnal asthma. Clin Sci 1992;83:227-32.

10 Martin RJ, Cicutto LC, Smith HR, Ballard RD, Szefler SJ Airways inflammation in nocturnal asthma. Am Rev Res pir Dis 1991;143:351-7.

11 Greening AP, Lowrie DB. Extracellular release of hydrogen peroxide by human alveolar macrophages: the relationship to cigarette smoking and lower respiratory tract infection. Clin Sci 1983;65:661-4.

12 Jackett PS, Andrew PW, Aber VR, Lowrie DB. Hydrogen peroxide and superoxide release by alveolar macrophages from normal and BCG-vaccinated guinea-pigs after intravenous challenge with Mycobacterium tuberculosis. $\mathrm{Br} \mathcal{F}$ venous challenge with $1981 ; 62: 419-28$.

13 Jarjour NN, Busse WW, Calhoun WJ. Enhanced production of oxygen radicals in nocturnal asthma. Am Rev Respir Dis 1992;146:905-11.

14 British Thoracic Society. Guidelines for the management of asthma in adults: chronic persistent asthma. $B M \mathcal{F}$ 1990;301:651-3.

15 Djukanovic R, Wilson JW, Britten KM. The effect of an inhaled corticosteroid in airway inflammation and the symptoms in asthma. Am Rev Respir Dis 1992;145:669-74.

16 von Essen SG, Robins RA, Sporzen JR, Thompson AB, McGranaghan SS, Rennard SI. Bronchoscopy with bronchoalveolar lavage causes neutrophil recruitment in lower respiratory tract. Am Rev Respir Dis 1991;144:848-54.

17 Walsh GM, Mermod JJ, Hartnell A, Kay AB, Wardlaw AJ Human eosinophil, but not neutrophil, adherence to IL 1 stimulated human umbilical vascular endothelial cells is 4 B1 (very late antigen-4) dependent. $\mathcal{f}$ Immunol 1991; 146:3419-23.

18 Dobrina A, Menegazzi R, Carlos TM, Nardon E, Cramer $\mathrm{R}$, Zacchi $\mathrm{T}$, et al. Mechanisms of eosinophil adherence to cultured vascular endothelial cells: eosinophils bind to the cytokine-induced endothelial ligand vascular cell adhesion molecule-1 via the very late activation antigen-4 integrin receptor. 7 Clin Invest 1991;88:20-6.

19 Bentley AM, Durham SR, Robinson BS, Cromwell O, Kay $A B$, Wardlaw AJ. Expression of the endothelial and leucocyte adhesion molecules ICAM-1, E-selectin and VCAM-1 in the bronchial mucosa in steady state asthma and allergen induced asthma (abstract). Thorax 1992;47:852.

20 Bradding P, Feather IH, Howarth PH, Mueller R, Roberts $\mathrm{JA}$, Britten $\mathrm{K}$, et al. Interleukin-4 is localised to and released by human mast cells. $\mathcal{F}$ Exp Med 1992;176:1381-5.

21 Thornhill MH, Kyan-aung U, Haskaard D. IL-4 increases human endothelial cell adhesivenes for T-cells but not for neutrophils. F Immunol 1990;144:3060-5.

22 Rand TH, Silberstein DS, Kornfeld H, Weller PF. Human eosinophils express functional interleukin 2 receptors. $\mathcal{f}$ Clin Invest 1991;88:825-32. 